\title{
Tourism development challenges on the Dead Sea shore
}

\author{
Jan A. Wendt
}

Institute of Geography, University of Gdańsk, Bażyńskiego 4, 80-309 Gdańsk, Poland, e-mail: jan.wendt@ug.edu.pl

\begin{abstract}
The Dead Sea along with Jerusalem belongs to one of the most well-known spots visited by tourists in Israel. Because of many factors, such as the water level of the Dead Sea at a depth of $430 \mathrm{~m}$ b.s.l. (in 2015), average salinity of 26\%, hot springs and many healing salts located there, it is a unique tourist attraction on a global level. Its attractiveness is heightened by its proximity to other sites of interest , such as the Jewish fortress at Masada, Jericho, Qumran, where the Dead Sea Scrolls were found, as well as Petra, Madaba and Al-Karak on the Jordanian side of the Dead Sea. High salinity and a microclimate create perfect conditions for the development of health resorts and medical tourism. Extracting healing salts from its waters for the needs of the chemical industry is important for both the economy and medical tourism. However, as a consequence of the agricultural and urban use of the waters of the River Jordan, which flows into the Dead Sea, a persistent decrease in the lake water level has been observed over the last century. This has created a number of economic and political issues. The problems which still have to be resolved are associated with the Red Sea-Dead Sea Conduit (Canal), the division of Jordan's water resources, conservation of the unique reservoir of the Dead Sea and the threat of hindering the development of tourism within the region. The presentation of these issues is the main aim of this research paper. The study is based on the analysis of changes in tourism flows, results of research studies and the prognosis of changes in the water level of the Dead Sea. It presents an assessment of the effects of this phenomenon on the tourist economy. At the current level of tourism flows within the region, the tourist capacity of local beaches will be exceeded in areas where the most popular tourist resorts are located. Increased expenditure on development of tourism infrastructure in the coastal zone can also be observed. The predicted decreasing water level will result in further modifications and expansion of tourism infrastructure, decreased accessibility to the coastline for tourists, increased costs of visiting and may lead to an ecological disaster.
\end{abstract}

Key words: Dead Sea, River Jordan, Israel, Jordan, tourism, medical tourism, accommodation, environmental issues

\section{Introduction}

The Dead Sea is one of the most popular tourist destinations in Israel. Due to a number of factors, such as the water level at a depth of $430 \mathrm{~m}$ b.s.l. (in 2015) average salinity of $26 \%$, hot springs and many healing salts located there, it is a unique tourist destination. In addition to these natural features, its attractiveness is increased by its proximity to other sites of interest, such as the Jewish fortress at Masada, Jericho, the image of Qumran, the place where Dead Sea Scrolls were found, as well as Petra, Madaba and Al-Karak which are on the Jordanian side of the Dead Sea (Wójtowicz and Wójtowicz 2015). Its high level of salinity and microclimate provide excellent conditions for the development of recreational, specialist, medical and wellness tourism. Extracting healing salts from its waters for the needs of chemical industry plays a crucial role in the economy and medical tourism. However, as a consequence of the agricultural and urban use of the waters of the River Jordan, which flows into the Dead Sea, although currently at a greatly reduced rate, there has been a constant decrease in the lake water level over the last 70 years. This decrease creates a number of economic and political issues. The problems, which still have to be resolved, are associated with the Red Sea-Dead Sea Conduit, which is still in the first stage planning. This creates conflicting demands; on the one hand of conservation of the unique reservoir of the Dead Sea, and on the other, the development of tourism within the region. In the last 85 years the water level of the Dead Sea has fallen by $34 \mathrm{~m}$ to a depth of $430 \mathrm{~m}$ b.s.l. in 2015 .

In a significantly shorter period of time, from 1990 onward, rapid development of the tourist industry has taken place within the region. The Holy Land, which had earlier been visited mainly by pilgrims who rarely travelled outside Jerusalem and Galilee, has become a destination of hundreds of thousands of tourists, and the Tel Aviv Ben Gurion International Airport has become the largest and busiest airport in the region (Wendt 2011). Following the end of the numerous con- 
flicts between Israel and its neighbours the Dead Sea region became the target of mass medical and wellness tourism, as well as leisure tourism, in both Jordanian and Israeli locations. Owing to the high concentration of mineral salts and their unique chemical composition the extraction of magnesium and potassium has been undertaken on an industrial scale. Natural salts extracted from the Dead Sea waters along with the local microclimate characterized by high amounts of oxygen and low UVB exposure, create great conditions for healing skin diseases (Abdel-Fattah and Pingitore 2009) and providing treatment related to balneotherapy (Neumann et al. 2001; Ablin et al. 2013).

In the period 1995-2015, tourism flows in Israel increased from 2.2 million to over 3.1 million and in Jordan from 1.1 million to 4.8 million. Charter flight transportation to Tel Aviv airport grew by $71 \%$ between 2010 and 2013 for tourists from Poland alone (Ilieş and Wendt 2015). Nearly half of the tourists and excursionists visiting Israel decide to stay by the Dead Sea, especially on its Israeli shore. A persistent decrease in the lake water level over the last 83 years (to 2015), which was around $44 \mathrm{~m}$, led to the formation of fluvial terraces, sinkholes, a decrease in the level of groundwater (Abu Ghazleh et al. 2011) and shrinkage of the shoreline, which is also gradually receding from the tourist infrastructure. At the same time, ecological degradation of the reservoir is intensified and may be further worsened if a canal connecting the Dead Sea and the Red Sea is built.

\section{Research aim and methodology}

The aim of this study is to present the importance of this lake in terms of tourism and economy, and additionally to indicate the issues resulting from the continuous process of water level decrease. In the years 1930-2010 the water level fell by $34 \mathrm{~m}$, from 389 m b.s.l. in 1932 to $423 \mathrm{~m}$ b.s.l. in 2010 and to $430 \mathrm{~m}$ b.s.l. in 2015. Since 1932 the lake's area has decreased by $46.1 \%$, from 1082 to $583 \mathrm{~km}^{2}$ in 2010 (Abu Ghazleh et al. 2011; IOLR 2016) Spatial reduction and shallowing of the reservoir have resulted in a number of issues associated with maintaining and developing tourism infrastructure.

Classical research methods have been used in this research, as well as description and analysis of literature. These include an analysis of the size and trends in the changes of tourism flows in the studied region based on the background data for Israel and Jordan. Historical analysis and the widely used cartographic (comparison of maps from different times) method were helpful in assessing the changes in the landscape which was created by the lowering water levels of the Dead Sea. To assess and indicate the main physical geographical and economic factors affecting changes in the water level, reductive reasoning wasapplied. To determine the difficulties created by tourism flows on the Dead Sea shore simple statistical methods were used. In the summery, an analysis of the influence of changes in the Dead Sea water level on the development of the tourist economy within the region are presented.

\section{Study area}

The Dead Sea is located in a depression in the central part of the Jordan Rift Valley, which reaches East Africa in the south and Syria in the north. It adjoins the Judean Mountains in the west and the Moab Plateau in the east. The lake is divided by the international border between Israel and Jordan, but on the western shore there is a Palestinian territory administered by Israel (Fig. 1). The Dead Sea is located at the lowest point on Earth. It is a unique geographical, geological and biological ecosystem. At the same time, it is a unique tourist attraction on a global scale with well-developed hotel and transport infrastructure sufficient for the needs of

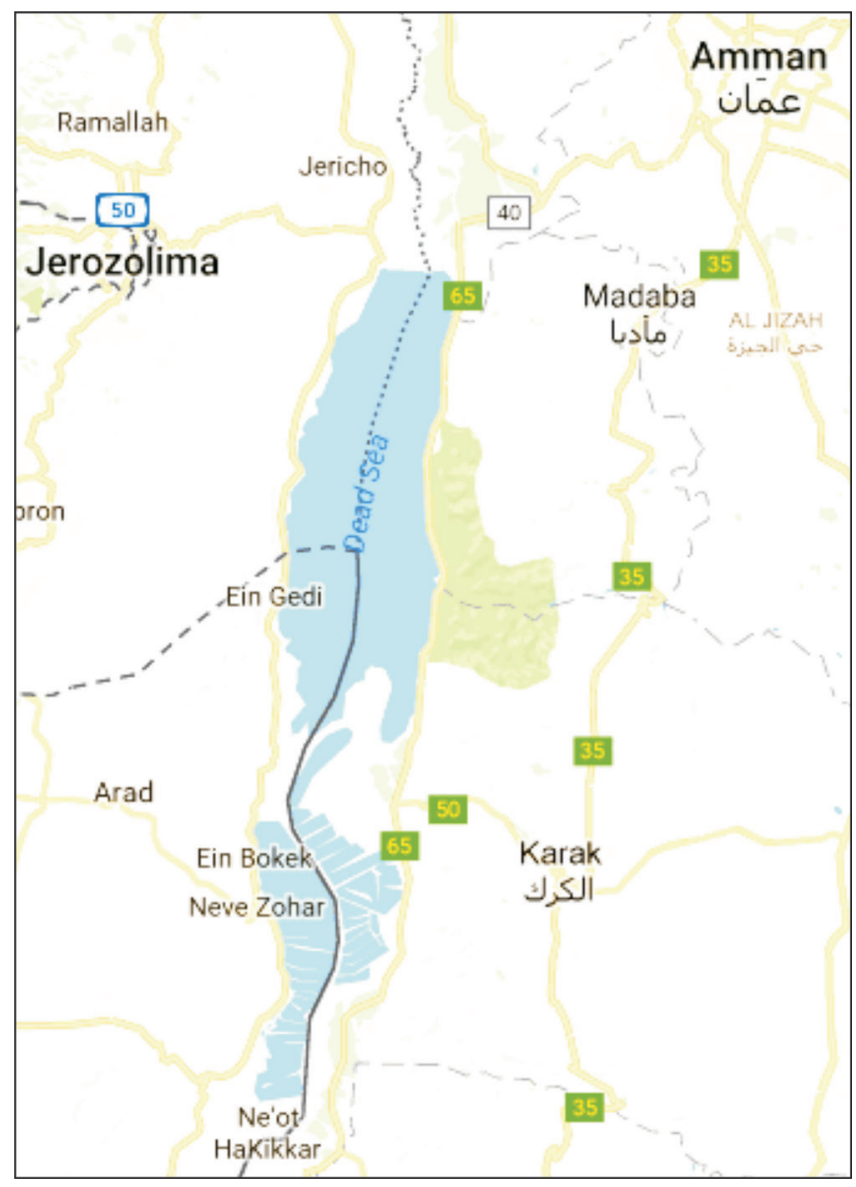

Fig. 1. Dead Sea divided between Israel and Jordan Source: Google maps (2016). 
Table 1. Water input into the Dead Sea prior to and after fresh water resource development (WRD)

\begin{tabular}{lcc}
\hline $\begin{array}{c}\text { Fresh water } \\
\text { resource }\end{array}$ & $\begin{array}{c}\text { Water input prior } \\
\text { WRD }\left[\mathrm{km}^{3} \mathrm{yr}^{-1}\right]\end{array}$ & $\begin{array}{c}\text { Water input after } \\
\text { WRD }\left[\mathrm{km}^{3} \mathrm{yr}^{-1}\right]\end{array}$ \\
\hline River Jordan & 1.207 & 0.100 \\
\hline Dead Sea tributaries & 0.463 & 0.180 \\
\hline Groundwater & 0.220 & 0.140 \\
\hline Total & 1.890 & 0.420 \\
\hline
\end{tabular}

Source: Modified after Salameh and El-Naser 2000; Abu Ghazleh et al. 2011.

tourism flows on the Israeli side as well as from the Jordanian side. Average salinity of the Dead Sea is about $26 \%$. It reaches $22 \%$ on the surface and approximately $36 \%$ at a depth of $50 \mathrm{~m}$. As a result of the lowering water level, the emerging and growing Lisan Peninsula has divided the lake into two parts. The deeper northern part reaches $770 \mathrm{~m}$ b.s.l. and the shallower southern portion has actually disappeared and is used for the industrial extraction of potassium (Khlaifat et al. 2010).

The extraordinary climate "supports" the development of tourism. Weather conditions such as cloudless, dry air and high air temperatures dominate the area throughout the year. The average annual precipitation is $50 \mathrm{~mm}$ and the average monthly temperature vary from 32 to $39^{\circ} \mathrm{C}$ in summer, and from 20 to $23^{\circ} \mathrm{C}$ in winter. On average, there are 330 days per year without rainfall and 200 days with temperatures exceeding $30^{\circ} \mathrm{C}$. Due to increased air pressure, air near the lake contains more oxygen - from 3 to $5 \%$ (Hecht and Gertman 2003), which helps in healing health issues associated with the circulatory system.
Table 2. Water volume and surface area losses related to the lake level changes since 1932. For the period 2010-2020 the expected values are shown

\begin{tabular}{cccccc}
\hline \multirow{2}{*}{ Period } & $\begin{array}{c}\text { Level change } \\
\text { [m b.s.I. }]\end{array}$ & \multicolumn{2}{c}{ Water volume lost } & \multicolumn{2}{c}{ Surface area lost } \\
\cline { 3 - 6 } & {$\left[\mathrm{km}^{3}\right]$} & {$\left[\mathrm{km}^{3} \mathrm{yr}^{-1}\right]$} & {$\left[\mathrm{km}^{2}\right]$} & {$\left[\mathrm{km}^{2} \mathrm{yr}{ }^{-1}\right]$} \\
\hline $1932-1955$ & $389-399$ & 3.0 & 0.13 & 78.1 & 4.0 \\
\hline $1955-1978$ & $399-400$ & 6.7 & 0.29 & 286.8 & 11.7 \\
\hline $1978-1995$ & $400-409$ & 6.0 & 0.36 & 56.3 & 3.3 \\
\hline $1995-2009$ & $409-422$ & 6.9 & 0.49 & 72.5 & 5.2 \\
\hline $2010-2020$ & $423-433$ & 3.4 & 0.34 & 55.8 & 5.6 \\
\hline
\end{tabular}

Source: After Abu Ghazleh et al. 2011.

\section{Results and discussion}

The results of conducted research (Salameh and El-Naser 2000; Gertman and Hecht 2002; Al-Khlaifat 2008; Abu Ghazleh et al. 2009; Abu Ghazleh et al. 2011), show that since the mid-twentieth century the Dead Sea is drying out at an increasing pace. This is mainly caused by increased extraction of water for agricultural purposes as well as a lower level of annual precipitation.

The presented data (Table 1) reveal that the factors responsible for the desiccation of the Dead Sea mainly derive from a more than ten-fold decrease in the feeding of the River Jordan and to a lesser extent, the reduced flow of other rivers into the lake reservoir. Because of the significantly increased water extraction, global warming and decreasing precipitation, the water level decline in the years 1932-1978 was $11 \mathrm{~m}(0.24 \mathrm{~m}$ per year). In the following period 1978-1995, the water level decreased by $9 \mathrm{~m}(0.53 \mathrm{~m}$ per year). In the years 1995-2009, it fell by $13 \mathrm{~m}$, with a pace of $0.93 \mathrm{~m}$ per

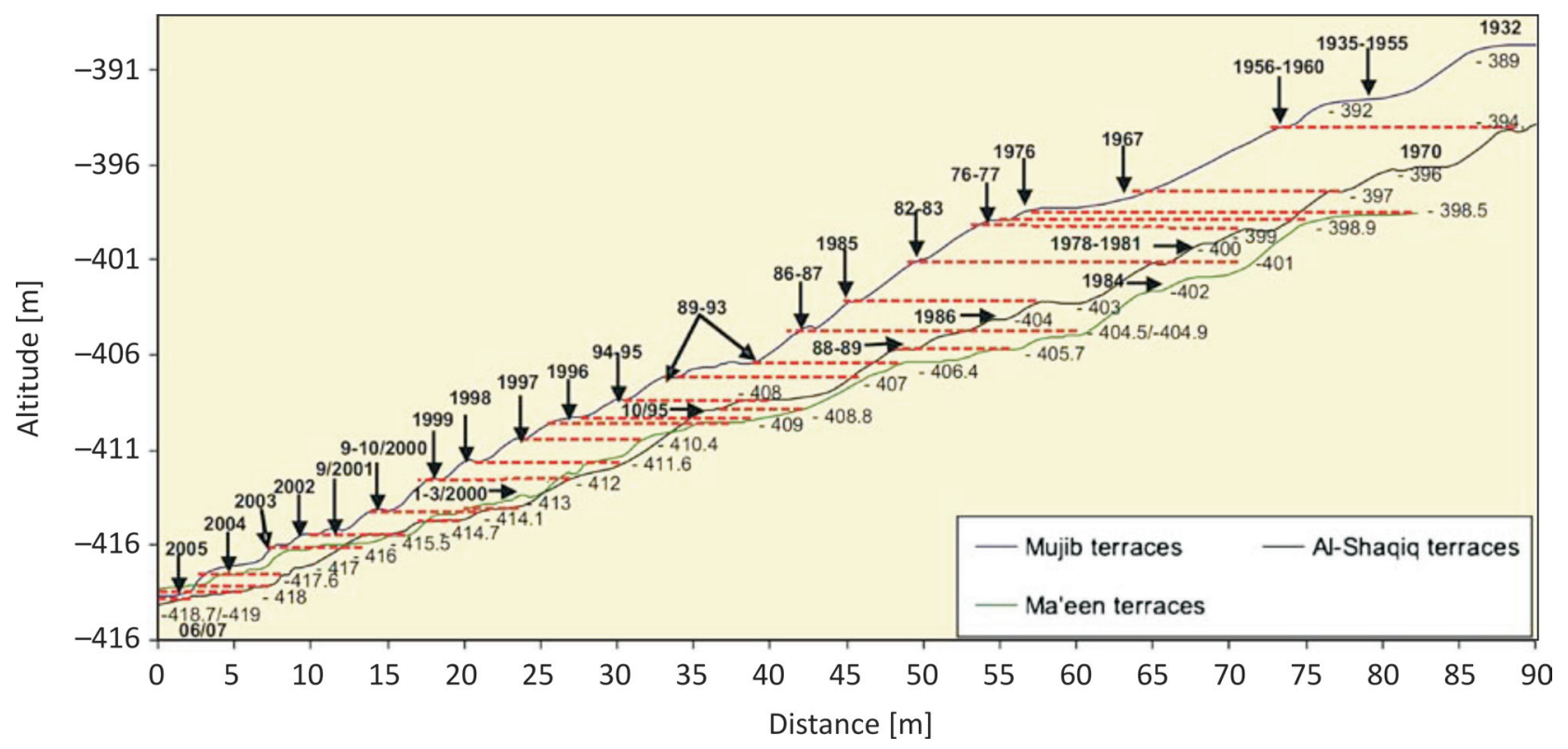

Fig.2. Three profiles of the Dead Sea terraces surveyed by DGPS and dated according to the recorded Dead Sea levels Source: Abu Ghazleh et al. (2011). 
Table 3. Changes in the number of tourists (in the thousands) in Israel and Jordan in the years 1995-2015

\begin{tabular}{|c|c|c|c|c|c|c|c|c|c|}
\hline \multirow{2}{*}{ Country } & \multicolumn{9}{|c|}{ Year } \\
\hline & 1995 & 2000 & 2005 & 2010 & 2011 & 2012 & 2013 & 2014 & 2015 \\
\hline Israel (Total) & - & - & - & 3444 & 3362 & 3520 & 3540 & 3251 & 3109 \\
\hline Jordan (Total) & - & - & - & 8078 & 6813 & 6314 & 5389 & 5327 & 4800 \\
\hline Israel without 1 day tourists & 2215 & 2417 & 1903 & 2803 & 2820 & 2886 & 2962 & 2927 & 2799 \\
\hline Jordan without 1 day tourists & 1075 & 1580 & 2987 & 4207 & 3960 & 4162 & 3945 & 3990 & - \\
\hline
\end{tabular}

Source: author's elaboration based on: Bachner 2016; CBS 2016; MOTA 2016; Obeidat 2016; WBG $2016 \mathrm{a}, 2016 \mathrm{~b}$.

year. Prognosis based on the cited literature predicts an accelerating pace of lowering of the Dead Sea water level up to $1 \mathrm{~m}$ annually in the period 2009-2020 (Table 2). However, on the 01.01.2016 the Dead Sea water level reached $429.85 \mathrm{~m}$ (Dead Sea Data Summary 2016) which means that the rate of water level decrease rose from the forecasted $1 \mathrm{~m}$ per year to $1.31 \mathrm{~m}$ per year. This is a $30 \%$ increase in the actual rate of fall of the water level relative to the predicted one (Abu Ghazleh et al. 2011).

As a consequence of the falling water level, the shore is withdrawing, fluvial terraces Al-Shaqiq, Ma'een and Mujib were created on the Jordanian side of the Dead Sea (Abu Ghazleh et al. 2009), sinkholes appeared on both sides and the groundwater level decreased (Fig. 2).

Detailed data from 2015 indicates that the process of drying out is accelerating. In December 2015 the rate of water level decline was $18 \mathrm{~cm}$ compared to $3 \mathrm{~cm}$ in November, $6 \mathrm{~cm}$ in December 2014 and $3 \mathrm{~cm}$ in December 2013. In January 2015 the water level reached $428.85 \mathrm{~m}$ which is, in fact, an actual decrease in the water level by $1 \mathrm{~m}$ in 2015, but in the period 2005-2015 the actual average annual decline in the water level was $1.24 \mathrm{~m}$ (Kibuc Ein Gedi 2016).

The continuing process of drying out of the Dead Sea has a negative impact not only on the environment and ecological processes, but also on human activity, which is clearly visible in the case of tourist development. In the last twenty years, the overall number of tourists in Israel (not including day excursionists) increased by $27 \%$, from 2.2 million in 1995 to 2.8 million in 2015. In the same period, the number of tourists in Jordan increased by $370 \%$. In 2015 both countries registered a decrease in the number of tourists, $4.4 \%$

Table 4. Accommodation in Jerusalem and Amman

\begin{tabular}{lrr}
\hline Type of accommodation & Jerusalem & Amman \\
\hline Hotels & 86 & 119 \\
\hline Apartments & 108 & 94 \\
\hline Hostels & 11 & 4 \\
\hline Guesthouses & 13 & 5 \\
\hline Other & 9 & 1 \\
\hline Total & 227 & 196 \\
\hline
\end{tabular}

Source: author's elaboration (29.03.2016) based on Booking.com service. in Israel and 9.9\% in Jordan (Table 3), but the region of the Dead Sea is still visited by hundreds of thousands of visitors every year.

The size of tourism flow and the importance of tourism can be confirmed by the number of hotels existing in both capitals and the share of wealth deriving from tourism in GDP, which was 7\% in Israel (WDA 2016a) and 20.7\% in Jordan (WDA 2016b) in 2015.

Located at a distance of an hour's drive from the northern shores of the Dead Sea, the capitals of both countries offer a perfect starting point for one day trips. In 2016 Booking.com, the popular website through which room reservations can be made, offers 227 accommodation facilities in Jerusalem, including 86 hotels, and 196 objects of this type in Amman, of which 119 are hotels (Table 4). In practice, in each of these 423 objects thousands of tourists buy one day trips to Masada, Jericho, Qumran, Madaba or the deservedly popular Dead Sea (Fig. 3).

According to the report Tourism in Israel 20002012 published by the Central Bureau of Statistics of Israel (CBS 2013), 51\% of tourists visiting Israel for the first time in the years 2000-2012 visited the Dead

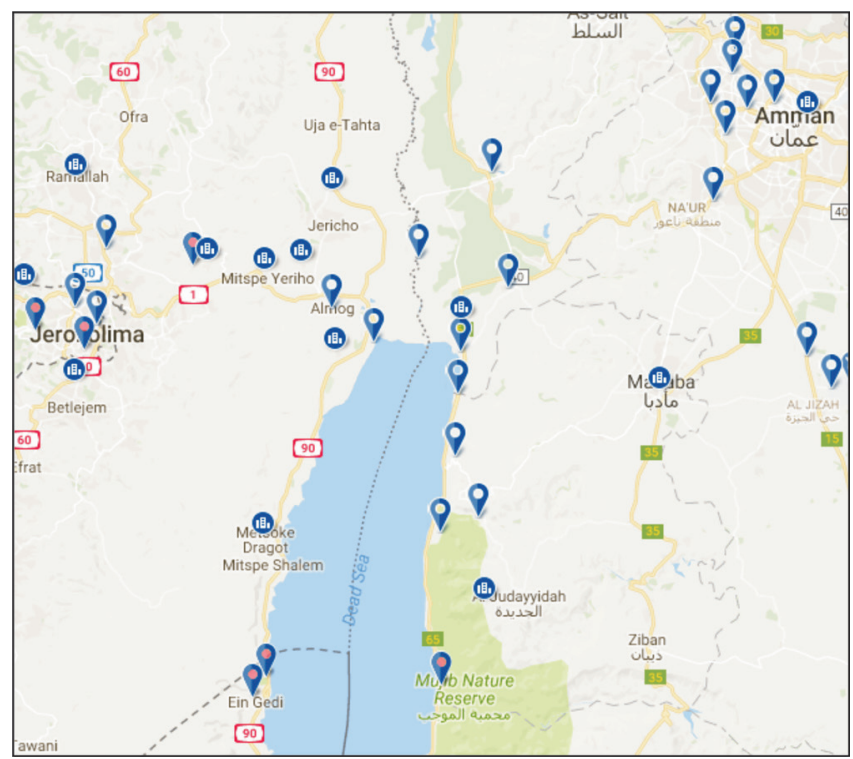

Fig. 3. Hotels and tourist resorts situated at Jerusalem, Amman and on the shoreline of the Dead Sea (north part)

Source: Booking.com service (2016). 
Table 5. Accommodation by the Dead Sea in Israel and Jordan

\begin{tabular}{lcc}
\hline \multicolumn{1}{c}{ Type of accommodation } & Israel & Jordan \\
\hline Hotels & 15 & 21 \\
\hline Apartments & 7 & 3 \\
\hline Hostels & 4 & 2 \\
\hline Guesthouses & 3 & - \\
\hline Holiday resorts & 1 & - \\
\hline Houses and holiday cabins & 11 & 1 \\
\hline Total & 41 & 27 \\
\hline
\end{tabular}

Source: author's elaboration (30.03.2016) based on Booking.com service.

Sea. Jerusalem was visited by $77 \%$ of tourists, Tel Aviv by $56 \%$, Tiberias and the Sea of Galilee by $44 \%$, both Haifa and Eilat by $16 \%$. In the record-breaking year of 2013 , in terms of tourism, the most visited places in Israel were Jerusalem (75\%), followed by Tel Aviv (64\%), with the Dead Sea in third place (51\%) followed by the Sea of Galilee (44\%) and Nazareth in fifth place with a $35 \%$ share in tourism flow (Reinstein 2014). According to data from the Israeli CBS, in 2014 half of the foreign tourists visiting Israel visited the Dead Sea. In general, Israeli citizens dominate the holidaymakers. In January 2015 they made up $87 \%$ of the 124000 tourists. In July of the same year the share of Israeli citizens of the total 214000 tourists was 88\% and in February 2016 they accounted for $82 \%$.

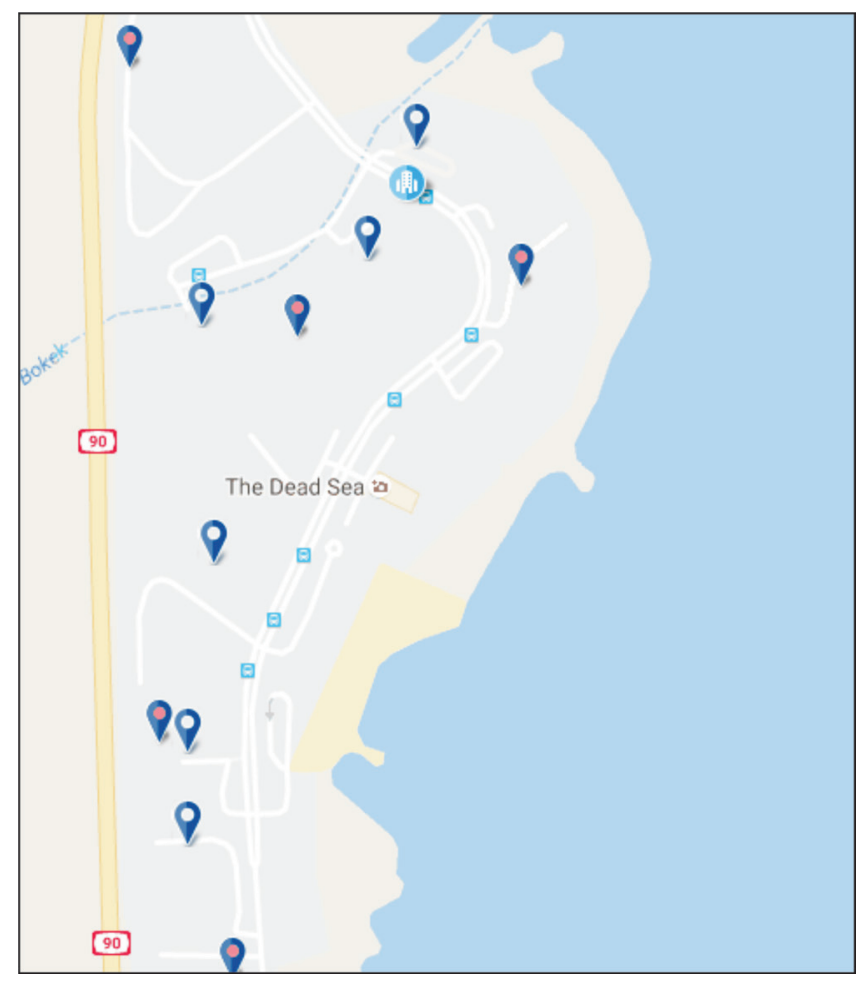

Fig. 4. Hotels at Ein Bokek (Israel)

Source: Booking.com service (2016).
Evidence of the large scale of the phenomenon of tourism in the Dead Sea region can be found in the number of year-round accommodation spots located directly on the shore of the lake in Israel and Jordan. Various types of spa and wellness hotels, clinics, medical centres, guesthouses, hostels, apartments, houses and holiday cabins offer thousands of beds in 41 establishments in Israel and 26 in Jordan (Table 5). 16 of them on the Israeli shore and 9 on the Jordanian side advertise themselves by claiming they have direct access to the beach. In the case of the hostel in Ein Gedi the word "direct" means a distance of about $500 \mathrm{~m}$. Moreover, many of the 4 or 5 star hotels in Ein Bokek (Israel) are separated from the shore by the newly built road and nearby parking lots. In such cases tourists are taken to the beach by hotel minibuses.

The diversified location of most tourist objects by the Dead Sea in Israel and Jordan is also an interesting topic. The main tourist centers in Israel are characterized by significant geographical differentiation. Almog (with one accommodation facility) is located northeast of the northern shore in Israel. Kibbutz Ein Gedi (2) and Metsoke Dragot (1) are situated in the central part of the western coast of the Dead Sea. The largest are Ein Bokek (13), Neve Zohar (12), Ne'ot HaKikar (7) and Ein Tamar (5), which were built on the western coast of the second, smaller and shallower basin (Figs 4 and 5).

The development of tourist recreation centers by the South Basin of the Dead Sea results from simple

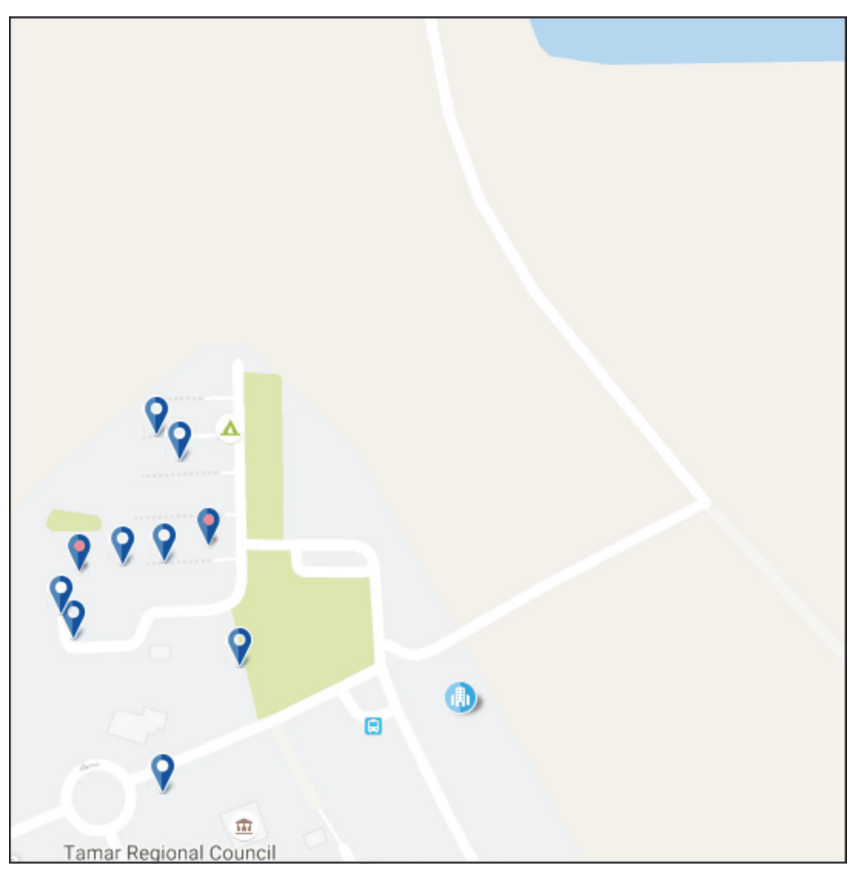

Fig. 5. Hotels at Neve Zohar (Israel)

Source: Booking.com service (2016). 


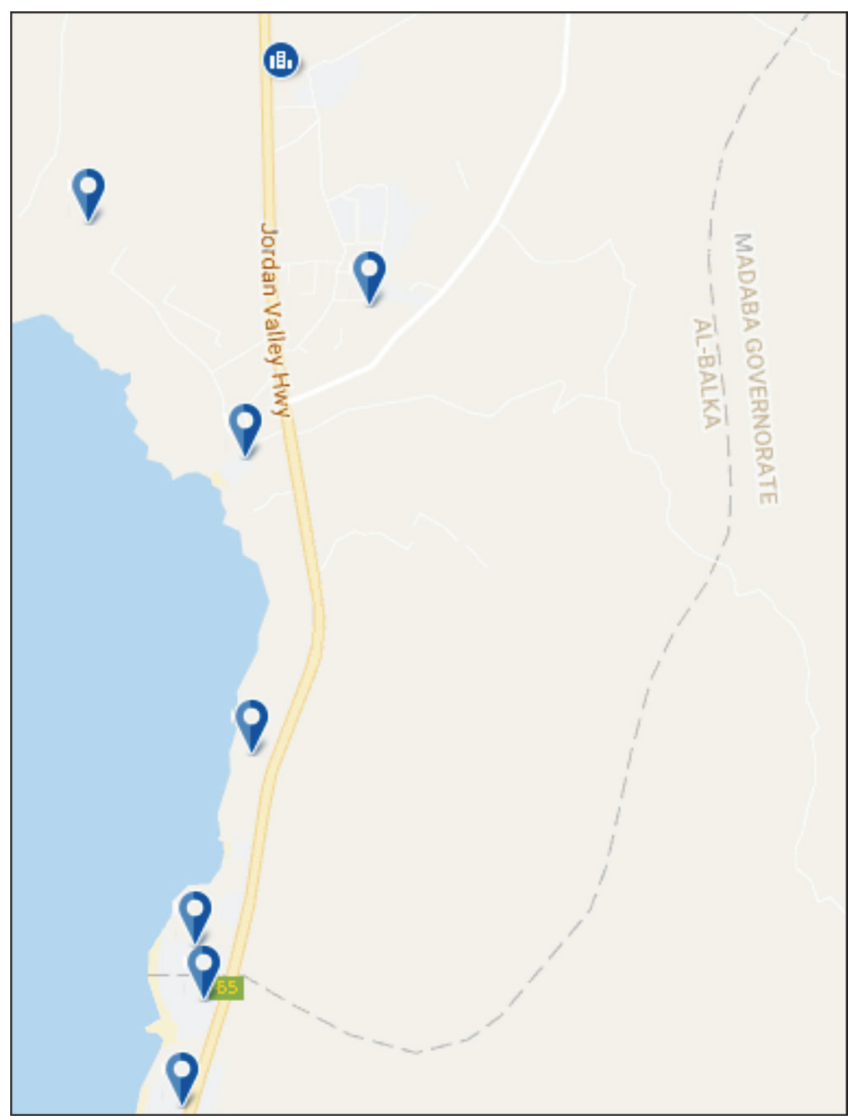

Fig. 6. Hotels and resorts at Sowayma on the north-east part of Dead Sea (Jordan)

Source: Booking.com service (2016).

political determinants. A significant part of the western coast of the reservoir, beside the Dead Sea Road highway, is controlled by Israel. Because of the governance, management, settlement and security issues, the biggest companies in the tourism industry prefer locating their objects by the Dead Sea, but at a distance from the Palestinian Authority territory. These conditions can be best met on the western shore of the smaller South Ba$\sin$. Due to the relatively short distances within Israel and a good network of highways, there are no transport accessibility limits when travelling. Similarly, a very rational decision was to localize holiday resorts in Jordan (Fig. 6).

The majority of these resorts are built on or near the eastern shore or in the north-east direction from the larger coast of the northern reservoir in Sowayma (12), nearby Madaba (11), Al-Salt (1) and in Al-Qastal (1). Only Ath Thughrah (1) is located east of the southern basin of the Dead Sea. Such localization is the result of easy transport accessibility as most tourist resorts are located in the region of the closest distance to the capital of the country. Additionally, the region is characterized by well-developed transport in- frastructure in comparison with the other desert parts of Jordan.

Precise data presenting the number of tourists and excursionists by the Dead Sea is actually impossible to find. The numbers of foreign tourists who go on one day excursions to the Dead Sea from the place where they are staying is not known. Neither is the number of tourists going there from Israel and Jordan. Statistical data from the Jordanian Ministry of Tourism and Antiquities (MOTA) state that the size of tourist movement in 2015 by the Dead Sea was 28.4 thousand people and 35.1 thousand in 2014. Out of these respectively 14.8 thousand (2015) and 16 thousand (2014) tourists were locals, 13.6 thousand (2015) and 19.1 thousand (2014) were foreign. Assuming that the tourists stayed for an average stay of one week, there were 198.8 thousand person-nights in 2015 and 245.7 thousand person-nights in 2014 (MOTA 2015). The number of person-nights divided by the number of days within a year will give us an approximate statistical number of tourists resting by the Jordanian shore of the basin. It is possible to assume that there were 545 people per day (2015) and 673 people per day (2014) in a relatively small fragment of the North shore of the lake.

Much higher values characterize the Israeli part of the Dead Sea shore (Table 6). Using the same assumptions, according to which the number of person-nights is divided by the number of days within a year, gives an approximate number of tourists per day. In 2008 there were 6015 holidaymakers resting on the Israeli shore of the sea, but in 2014 this number increased to 6140 . Even though it is impossible to assess the number of tourists swimming in the sea waters every day without conducting additional terrain or questionnaire based research, if we assume that only half of them went to the beach, we receive a number of approximately 3000 people daily who use the sea waters or stay on the beach in Ein Gedi, Ein Bokek, Neve Zohar, and in the southern less attractive part, which is not as popular because of

Table 6. Daily number of tourists (in the thousands) on the Israeli shore of the Dead Sea

\begin{tabular}{ccccc}
\hline \multirow{2}{*}{ Year } & \multicolumn{3}{c}{ Person-nights } & \multirow{2}{*}{ Person-nights per day } \\
\cline { 2 - 4 } & Israelis & Foreign tourists & Total & \\
\hline 2008 & 1616.4 & 578.9 & 2195.3 & 6.015 \\
\hline 2009 & 1662.5 & 462.8 & 2125.3 & 5.823 \\
\hline 2010 & 1642.1 & 565.1 & 2207.2 & 6.047 \\
\hline 2011 & 1714.6 & 586.8 & 2301.4 & 6.305 \\
\hline 2012 & 1728.9 & 586.8 & 2315.7 & 6.344 \\
\hline 2013 & 1739.3 & 573.4 & 2312.7 & 6.336 \\
\hline 2014 & 1705.2 & 524.1 & 2229.3 & 6.108 \\
\hline
\end{tabular}

Source: author's calculation based on data from Table 36. Guests, personnights, and occupancy in tourist hotels by continent of residence of guests and by selected localities (CBS 2016; p. 133). 
the nearby industrial zone. Additionally people traveling from cities such as Taba or Eilat to Jerusalem could stop by for an hour on the popular beach in Ein Bokek or go on a similar trip from Amman or Madaba to the Jordanian part of the shore.

\section{Conclusion}

The lowering of the water level of the Dead Sea creates a number of issues for the tourism industry. Tourist resorts are being built as close to the shoreline as possible for obvious reasons, and because of the falling water level they become increasingly further away from it. This is already visible in resorts such as Ein Gedi in the North Basin. At Ein Gedi and the northern Dead Sea location due to the shoreline receding further from the hotels, recreational infrastructure often ends in the middle of the beach. Lower parts of waterslides ending far from the lake, platforms hanging in the air, shower stands and small gastronomy far from the shoreline may be commonly seen. Parking lots previously located by the beach are now not only located on a cliff, but also a few hundred metres from the Dead Sea. However, in the Ein Bokek area, the main tourist destination, the regular salt remained in the pools and the water level is going up, which brings the water to the hotels.

The fluvial terraces such as Al.-Shaqiq, Ma'een and Mujib, on the Jordanian side (Abu Ghazleh et al. 2009) emerging due to the process of drying out look beautiful, but make it difficult for tourists to reach the shoreline, as well as presenting difficulties in the construction of new transport and hotel infrastructure. Every three or five years it is necessary to modernize, extend the decks leading to the water, and expand existing walkways for tourists. The emerging shoreline, which has eroded in the process of abrasion requires reinforcement and creates a potential hazard for careless tourists.

The lowering water table leads to the creation of sinkholes. Small sinkholes may also cause accidents; larger ones are capable of destroying the existing infrastructure, roads, buildings, as well as underground installations. If we look at the size of tourist movements it seems highly probable that tourist capacity has been exceeded on many easily accessible beaches such as the ones in Ein Gedi and Ein Bokek. The necessity to expand tourist infrastructure by the shoreline generates additional costs for businesses dealing with the tourist sector. Forecasted and progressive lowering of the water table level will lead to an ecological catastrophe, force expansion and further modifications of the infrastructure available for holidaymakers, decrease shoreline accessibility, and increase the overall costs which the tourists have to pay.

\section{References}

Abdel-Fattah A., Pingitore N.E., 2009, Low levels of toxic elements in Dead Sea black mud and mud-derived cosmetic products, Environ. Geochem. Health 31(4): 487-492.

Ablin J.N., Häuser W., Buskila D., 2013, Spa treatment (Balneotherapy) for fibromyalgia. A Qualitative-Narrative Review and a Historical Perspective, Evid. Based Complement. Alternat. Med. Article ID 638050:1-5.

Abu Ghazleh S., Abed A.M., Kempe S., 2011, The dramatic drop of the Dead Sea: Background, rates, impacts and solutions, [in:] Badescu V., Cathcart R.B. (eds) Macro-engineering seawater in unique environments. Arid Lowlands and water bodies rehabilitation, Springer-Verlag, BerlinHeidelberg: 77-105.

Abu Ghazleh S., Hartmann J., Jansen N., Kempe S., 2009, Water input requirements of the rapidly shrinking Dead Sea, Naturwissenschaften 96(5): 637-643.

Al-Khlaifat A.L., 2008, Dead Sea Rate of Evaporation, Am. J. Appl. Sci. 5(8): 934-942.

Avriel A., Fuchs L., Plakht Y., Cicurel A., Apfelbaum A., Satran R., Friger M., Dartava D., Sukenik S., 2011, Quality of life at the Dead Sea region: the lower the better? An observation study, Health Qual. Life Outcomes 9(38): 1-7.

Bachner M., 2016, More than three million tourists visited Israel in 2015, Breaking Israel News: 12 January 2016. Accessed on 13 June 2016 a: http://www.breakingisraelnews. com/58705/more-than-three-million-tourists-visitedisrael-2015-jerusalem/\#koEDGCZpOyFwBTtQ.97.

[Booking.com] Booking.com online accommodation booking website, 2016. Accessed on 29-30 March 2016 at: www.booking.com/searchresults.pl.html?

[CBS] Central Bureau of Statistics (Israel), 2013, Tourism in Israel 2000-2012, CBS Statistilite 135:1-15. Accessed on 20 June 2016 at: http://www.cbs.gov.il/statistical/touris2013e.pdf.

[CBS] Central Bureau of Statistics (Israel), 2016, Tourism and accommodation services. Accessed on 15 May 2016 at: http://www.cbs.gov.il/reader/?MIval=cw_usr_view_ SHTML\&ID=432.

Gertman I., Hecht A., 2002, The Dead Sea hydrography from 1992 to 2000, J. Mar. Syst. 35: 169-181.

Google, 2016, Google maps. Accessed on 25 July 2016 at: https://www.google.pl/maps.

Hecht A., Gertman I., 2003, Dead Sea Meteorological Climate, [in:] Nevo E., Oren A., Wassre S.P. (eds), Biodiversity of Cyanoprocaryotes, algae and fungi of Israel, University of Haifa, Haifa: 68-116.

Ilieş A., Wendt J.A., 2015, Geografia turystyczna. Podstawy teorii i zagadnienia aplikacyjne (Tourist geography. Basic theory and application issues), Wydaw. AWFiS, Gdańsk, 214 pp. (in Polish).

[IOLR] Israel Oceanographic and Limnological Research, 2016, Monitoring of the Dead Sea. Accessed on 18 June 2016 at: http://isramar.ocean.org.il/isramar2009/DeadSea/Default.aspx. 
Khlaifat A., Al-Khashman O., Qutob H., 2010, Physical and chemical characterization of Dead Sea mud, Mater. Char. 61(5): 564-568.

Kibuc Ein Gedi, official web page, 2016, Dead Sea data summary 2015. Accessed on 13 June 2016 at: http://www. eingedi.co.il/viewpage.asp?pagesCatID=13214\&siteNam $\mathrm{e}=$ eingedi

[MOTA] Ministry of Tourism and Antiquities, 2015, Statistics: Tourism Statistical Newsletter 2015. Accessed on 18 July 2016 at: http://www.mota.gov.jo/contents/Statistics. aspx.

[MOTA] Ministry of Tourism and Antiquities, 2016, Statistics: Tourism Statistical Newsletter 2016. Accessed on 18 July 2016 at: http://www.mota.gov.jo/contents/Statistics. aspx.

Neumann L., Sukenik S., Bolotin A., Abu-Shakra M., Amir M., Flusser D., Buskila D., 2001, The effect of balneotherapy at the Dead Sea on the quality of life of patients with fibromyalgia syndrome, Clin. Rheumatol. 20(1): 15-19.

Obeidat O., 2016, Tourism revenues dropped JD220m in 2015 - official figures, The Jordan Times: 6 March 2016. Accessed on 19 July 2016 at: http://www.jordantimes. com/news/local/tourism-revenues-dropped-jd220m2015-\%E2\%80\%94-official-figures.

Reinstein Z., 2014, 2013: Recorded year for incoming tourism, Ynet.news.com: 1 October 2014. Accessed on 19 July 2016 at: http://www.ynetnews.com/article/0,7340,L$4475168,00 \mathrm{html}$.
Salameh E., El-Naser H., 2000, Changes in the Dead Sea level and their impacts on the surrounding groundwater bodies, Acta Hydrochim. Hydrobiol. 28: 24-33.

Wendt J.A., 2011, Zarys geografii turystycznej (The outline geography of tourism) [CD version]. Wydaw. UG, Gdańsk, 126 pp. (in Polish).

[WBG] The World Bank Group, 2016a, International tourism, number of arrivals 1995-2014: Israel. Accessed on 18 July 2016 at: http://data.worldbank.org/indicator/ ST.INT.ARVL?locations=IL.

[WBG] The World Bank Group, 2016b, International tourism, number of arrivals 1995-2014: Jordan. Accessed on 18 July 2016 at: http://data.worldbank.org/indicator/ ST.INT.ARVL?locations=JO.

[WDA] World Data Atlas, 2016a, Israel - Travel \& Tourism Total Contribution to GDP. Accessed on 10 May 2016 at https://knoema.com/atlas/Israel/topics/Tourism/Traveland-Tourism-Total-Contribution-to-GDP/Total-Contribution-to-GDP-percent-share.

[WDA] World Data Atlas, 2016b, Jordan - Travel \& Tourism Total Contribution to GDP. Accessed on 10 May 2016 at https://knoema.com/atlas/Jordan/topics/Tourism/Travel-and-Tourism-Total-Contribution-to-GDP/Total-Contribution-to-GDP-percent-share.

Wójtowicz B., Wójtowicz P., 2015, Atrakcje turystyczne Jordanii i ich znaczenie dla rozwoju usług turystycznych, Pr. Kom. Geogr. Przemysłu PTG 29(3): 48-66 (in Polish, English summary). 